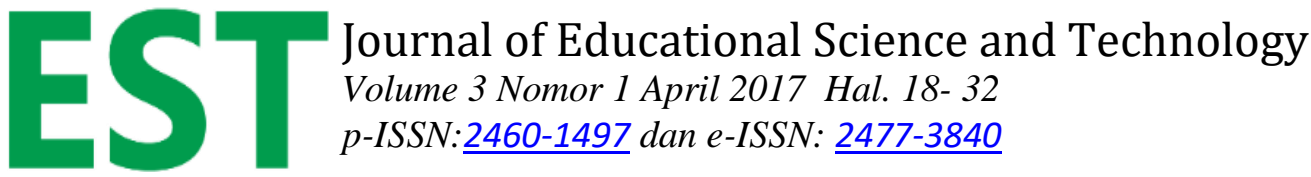

\section{Pengaruh model pembelajaran dan kemampuan awal terhadap kemampuan berpikir kritis dan pemahaman konsep peserta didik}

\author{
Muhammad Danial $^{1)}$ \\ Tabrani Gani' ${ }^{2)}$ \\ Husnaeni $^{3)}$ \\ ${ }^{1)}$ Pendidikan Kimia, Universitas Negeri Makassar \\ muhammaddaniel@unm.ac.id
}

(Received: Januari 2017; Reviewed: Februari 2017; Accepted: Maret 2017; Published: April 2017)

C2017 -EST Program Pascasarjana Universitas Negeri Makassar. Ini adalah artikel dengan akses terbuka dibawah licenci CC BY-NC-4.0 (https://creativecommons.org/licenses/by-nc/4.0/ ).

\begin{abstract}
The research aimed to know: (1) the difference of critical thinking ability of learners which was taught by guided inquiry learning model with the learners who learned the learning discovery learning model. (2) differences in the ability to understand the concepts of learners who are taught by guided inquiry learning model with learners who are taught by the learning model of discovery learning. (3) differences in the critical thinking ability of learners who have high initial ability and low initial ability are taught by guided inquiry learning model with learners who are taught by discovery learning learning model. (4) the difference in the ability of conceptual understanding between learners who have high initial ability and low initial ability that is taught by guided inquiry learning model with learners who are taught by discovery learning learning model. (5) the difference between the critical thinking ability of learners with high initial ability and low initial ability which is taught by guided inquiry learning model and discovery learning. (6) the difference between the difference in the understanding of highability early-skilled learners and low initial skills learned by guided inquiry learning and discovery learning models. Research is a quasi-experimental research (quasi experiment). The results of the research are: (1) There are differences of learning model to the critical thinking ability of learners; (2) There are differences of learning model to; (3) There is a difference of students' early ability to critical thinking ability of learners; (4) There is a difference in the learner's early ability to understand the concept of the learner; (5) There is a difference between the difference in the critical thinking ability of learners with high initial ability and low initial ability taught by the learning model; (6) There is a difference between the difference in understanding the concept of learners with high initial ability and low initial ability learned by the learning model.
\end{abstract}

Keywords: Guided Inquiry, Discovery Learning, Critical Thinking, Concept Understanding

ABSTRAK

Penelitian bertujuan untuk mengetahui: (1) perbedaan kemampuan berpikir kritis peserta didik yang dibelajarkan dengan model pembelajaran inkuiri terbimbing dengan peserta didik yang dibelajarkan model pembelajaran discovery learning. (2) perbedaan kemampuan pemahaman konsep peserta didik yang dibelajarkan dengan model pembelajaran inkuiri terbimbing dengan peserta didik yang dibelajarkan dengan model pembelajaran discovery learning. (3) perbedaan kemampuan berpikir kritis peserta didik 
yang memiliki kemampuan awal tinggi dan kemampuan awal rendah yang dibelajarkan dengan model pembelajaran inkuiri terbimbing dengan peserta didik yang dibelajarkan dengan model pembelajaran discovery learning. (4) perbedaan kemampuan pemahaman konsep antara peserta didik yang memiliki kemampuan awal tinggi dan kemampuan awal rendah yang dibelajarkan dengan model pembelajaran inkuiri terbimbing dengan peserta didik yang dibelajarkan dengan model pembelajaran discovery learning. (5) perbedaan antar selisih kemampuan berpikir kritis peserta didik yang berkemampuan awal tinggi dan kemampuan awal rendah yang dibelajarkan dengan model pembelajaran inkuiri terbimbing dan discovery learning. (6) perbedaan antar selisih pemahaman konsep peserta didik yang berkemampuan awal tinggi dan kemampuan awal rendah yang dibelajarkan dengan model pembelajaran inkuiri terbimbing dan discovery learning. Penelitian merupakan penelitian eksperimen semu (quasi eksperimen). Hasil Penelitian adalah: (1) Ada perbedaan model pembelajaran terhadap kemampuan berpikir kritis peserta didik; (2) Ada perbedaan model pembelajaran terhadap; (3) Ada perbedaan kemampuan awal peserta didik terhadap kemampuan berpikir kritis peserta didik; (4) Ada perbedaan kemampuan awal peserta didik terhadap pemahaman konsep peserta didik; (5) Ada perbedaan antar selisih kemampuan berpikir kritis peserta didik yang berkemampuan awal tinggi dan kemampuan awal rendah yang dibelajarkan dengan model pembelajaran; (6) Ada perbedaan antar selisih pemahaman konsep peserta didik yang berkemampuan awal tinggi dan kemampuan awal rendah yang dibelajarkan dengan model pembelajaran.

Kata kunci: Inkuiri Terbimbing, Discovery Learning, Berpikir Kritis, Pemahaman Konsep

\section{PENDAHULUAN}

Pembelajaran didefinisikan sebagai suatu sistem atau proses membelajarkan peserta didik yang direncanakan atau didesain, dan dievaluasi secara sistematis agar peserta didik dapat mencapai tujuan pembelajaran secara efektif dan efisien. Pada proses pembelajaran ada dua pihak yang terlibat sangat penting yaitu peserta didik dan guru. Suatu proses pembelajaran sangat dipengaruhi oleh kemampuan dan ketepatan guru dalam memilih dan menerapkan model pembelajaran (Sanjaya, 2006).

Terkait dengan hal tersebut, bahwa tujuan pembelajaran akan tercapai apabila perencanaan dan metode yang digunakan dapat mempengaruhi potensi dan kemampuan yang dimiliki peserta didik, dan keberhasilan tersebut akan tercapai apabila peserta didik dilibatkan dalam proses penemuan suatu konsep dengan mengembangkan kemampuan berpikirnya. Upaya untuk meningkatkan kemampuan tersebut adalah dengan menciptakan pembelajaran kimia yang inovatif, melibatkan aspek kognitif, afektif, dan psikomotor (Suyanti, 2010).

Kegiatan pembelajaran yang berpusat pada peserta didik sesuai dengan tujuan pembelajaran kimia yaitu mengembangkan aktivitas berpikir ilmiah. Kemampuan berpikir ilmiah sangat diperlukan peserta didik untuk memahami sebuah konsep, memecahkan masalah, dan mengembangkan kemampuan berpikir kritisnya. Kemampuan berpikir kritis dalam proses pembelajaran kimia memberikan arahan yang tepat dalam berpikir pada peserta didik untuk menganalisis gejala-gejala atau fenomena-fenomena yang muncul dalam memahami materi pelajaran. Berpikir kritis merupakan kemampuan berpikir secara rasional dan reflektif berdasarkan apa yang diyakini dan dilakukan (Ennis, 1996). Hal ini sejalan dengan Permendikbud No. 81 tahun 2013 tentang implementasi kurikulum yang menyebutkan bahwa kebutuhan kompetensi masa depan peserta didik yang diperlukan yaitu kemampuan berkomunikasi, kreatif dan berpikir kritis (Kemendikbud, 2013). Berpikir kritis harus memenuhi karasteristik kegiatan berpikir yang meliputi: analisis, sintesis, pengenalan masalah dan pemecahannya, kesimpulan dan penilaian. Jadi berpikir kritis dalam proses pembelajaran merupakan kompetensi yang akan dicapai serta alat yang diperlukan dalam mengkonstruksi pengetahuan peserta didik dalam memilah-milah informasi dan argumen. 
Pengetahuan memilah-milah informasi dan argument dalam berpikir kritis juga diperlukan untuk memahami sebuah konsep. Dengan belajar konsep peserta didik mampu mengklasifikasikan atau mengelompokkan peristiwa-peristiwa, objek-objek dan kegiatankegiatan yang dijumpainya dalam kehidupan sehari-hari. Konsep dapat dipahami sebagai suatu abstraksi yang mewakili objek, kejadian, hubungan yang mewakili atribut yang sama. Jean Piaget menyatakan bahwa dalam proses belajar, anak akan membangun sendiri konsep dan skemanya melalui pengalamannya. Hal tersebut menjadikan pemahaman konsep dalam pembelajaran penting, karena merupakan building block berpikir dan dasar proses mental yang lebih tinggi untuk merumuskan prinsip dan generalisasi (Dahar, 2011).

Prinsip dan generalisasi dalam pemahaman konsep diperlukan dalam mengembangkan potensi intelektual peserta didik. Konsep dapat menyederhanakan kerumitan lingkungan, sehingga dapat membantu mempelajari sesuatu yang baru, luas, dan lebih maju. Adanya konsep juga dapat memungkinkan pelaksanaan pengajaran, dan mempelajari dua hal yang berbeda dalam kelas yang sama (Hamalik, 2001).

Hasil observasi yang dilakukan di SMA Negeri 22 Makassar, bahwa proses pembelajaran kimia pada umumnya masih berpusat pada guru, belum memaksimalkan pencapaian tujuan pendidikan kimia. Objek kimia yang bersifat abstrak dan pemilihan model pembelajaran yang kurang tepat, menjadi faktor penyebab sulitnya belajar bagi peserta didik. Selain hasil observasi, hasil wawancara dengan guru kimia diperoleh informasi bahwa peserta didik cenderung menghafalkan konsep kimia seperti dalam buku paket mereka, sehingga kemampuan menganalisa, mensintesa, dan mengevaluasi (berpikir kritis) atas kumpulankumpulan fakta dan konsep kimia sangat rendah, ini dibuktikan ketika guru meminta peserta didik memberikan contoh selain yang tertera dalam buku paket, peserta didik tidak bisa menjawabnya. Selain itu, peserta didik kurang termotivasi di dalam kegiatan belajar. Hal ini dibuktikan dari hasil nilai peserta didik pada materi larutan elektrolit dan nonelektrolit kelas X IPA SMA Negeri 22 Makassar pada tahun sebelumnya, menunjjukkan $63 \%$ peserta didik dapat menyelesaikan soal hafalan pada kegiatan mengingat. Namun dalam mengerjakan soal yang menuntut kemampuan pemahaman konsep (C2 dan C3) hanya 30\% peserta didik yang mampu menjawabnya dan untuk kemampuan berpikir kritis (C4 dan C5) hanya $17 \%$ peserta didik yang mampu menyelesaikannya dengan benar. Begitupun hasil wawancara dengan beberapa peserta didik, diketahui bahwa sebagian dari mereka tidak bisa mengerjakan soal-soal yang menuntut penalaran tinggi.

Berdasarkan kenyataan tersebut diatas, maka peneliti tertarik untuk menerapkan model pembelajaran inkuiri terbimbing pada materi larutan elektrolit dan nonelektrolit. Pembelajaran materi larutan elektrolit dan nonelektrolit akan melibatkan peserta didik dalam proses penemuan suatu konsep dengan mengembangkan kemampuan berpikir kritisnya berdasarkan informasi-informasi yang diberikan oleh guru melalui kegiatan mengamati, merumuskan hipotesis,menyelidiki dan menganalisis . Hal ini sesuai dengan karasteristik model pembelajaran inkuiri terbimbing, dimana metode pembelajaran ini menekankan pada pembelajaran melalui penyelidikan, memberikan kesempatan kepada peserta didik untuk bereksplorasi (Kuhlthau, 2007). Dalam pembelajaran inkuiri peserta didik tidak hanya dituntut menguasai pelajaran, akan tetapi bagaimana mereka menggunakan potensi yang dimilikinya, dapat menumbuhkan sikap percaya diri (self-belief).

Model pembelajaran yang juga bertitik tolak dari proses penemuan adalah model discovery learning. Pembelajaran dengan menggunakan discovery learning dapat melatih peserta didik meningkatkan pemahaman konsep dan kemampuan berpikir kritisnya melalui kegiatan mengamati, menanya, mencoba, menalar dan mengkomunikasikan melalui sintaksnya seperti pada tahap stimulation, peserta didik diajak untuk mengamati, tahap problem statement, peserta didik diajak untuk menanya dan mengumpulkan informasi, tahap data collection, peserta didik diajak untuk menalar, tahap data processing, peserta didik diajak untuk menalar dan menanya dan tahap terakhir verification, peserta didik diajak untuk menalar dan mengkomunikasikan (Kemendikbud, 2013).

Faktor lain yang harus diperhatikan dalam pembelajaran kimia adalah kemampuan awal peserta didik (Ahmad, 2012). Kemampuan awal ini menggambarakan kesiapan peserta didik dalam menerima pelajaran yang akan disampaikan oleh guru. Kemampuan awal juga 
merupakan modal bagi peserta didik dalam melakukan aktivitas pembelajaran dan memberikan dampak positif terhadap proses dalam memperoleh pengetahuan yang lebih lanjut ( Dochy, 1996). Dengan memiliki kemampuan awal yang memadai maka akan sangat mendukung proses pembelajaran maupun dalam pencapaian hasil belajar kimia.

\section{TINJAUAN PUSTAKA}

\section{Model Pembelajaran}

Model pembelajaran merupakan kerangka konseptual yang melukiskan prosedur yang sistematis dalam mengorganisasikan pengalaman belajar untuk mencapai tujuan belajar tertentu, berfungsi sebagai pedoman bagi para perancang pembelajaran dan para pelajar dalam merencanakan aktifitas pembelajaran. Dengan demikian, aktifitas pembelajaran benarbenar merupakan kegiatan bertujuan yang tertata secara sistematis (Trianto, 2009). Hal ini sejalan dengan apa yang dikemukakan oleh Eggen dan Kauchak ( 2012) bahwa model pembelajaran memberikan kerangka dan arah bagi guru untuk mengajar suatu materi pembelajaran sehingga tujuan pembelajaran dapat tercapai.

\section{Pemahaman Konsep}

Herron (1977) mendefenisikan konsep merupakan suatu abstraksi yang melibatkan hubungan antar konsep (relational concept) yang dibentuk oleh individu dengan mengelompokkan objek, merespon objek tersebut dan kemudian memberi label (concept by defenotion). Taksonomi Bloom dalam Anderson (2010) pemahaman (comprehension) merupakan kemampuan peserta didik membuktikan hubungan yang sederhana diantara fakta-fakta konsep.

Rosser dalam (Dahar, 2011) konsep adalah suatu abstraksi yang mewakili satu kelas objek, kejadian, kegiatan atau hubungan yang mempunyai atribut yang sama. Seseorang dikatakan memahami sesuatu jika ia telah dapat mengorganisasikan dan mengutarakan kembali apa yang dipelajarinya dengan menggunakan kalimatnya sendiri. Peserta didik tidak lagi mengingat dan menghafal informasi yang diperoleh, melainkan harus dapat memilih dan mengorganisasikan informasi tersebut. Pemahaman bukan hanya sekedar mengingat fakta, akan tetapi berkenan kemampuan menjelaskan, menerangkan, menafsirkan atau kemampuan menangkap makna atau arti suatu konsep.

Konsep merupakan buah pemikiran seseorang atau sekelompok orang yang dinyatakan dalam defenisi sehingga melahirkan produk pengetahuan. Konsep diperoleh dari fakta, peristiwa, pengalaman, melalui generalisasi dan berpikir abstrak. Konsep berkembang sejalan dengan pengalaman-pengalaman selanjutnya dalam situasi, peristiwa, perlakuan ataupun kegiatan yang lain, baik yang diperoleh dari bacaan ataupun pengalaman langsung. Konsep mewakili sejumlah objek yang mempunyai ciriciri yang sama dan dituangkan dalam suatu kata ( Trianto, 2009 ).

\section{Kemampuan Berpikir Kritis}

Berpikir kritis merupakan salah satu proses berpikir tingkat tinggi yang dapat digunakan dalam pembentukan sistem konseptual peserta didik. Beyer dalam Slavin (2009) mendefenisikan berpikir kritis adalah kemampuan (1) menentukan kredibilitas suatu sumber, (2) membedakan antara yang relevan dari yang tidak relevan, (3) membedakan fakta dari penilaian, (4) mengidentifikasi dan mengevaluasi asumsi yang tidak terucapkan, (5) mengidentifikasi bias yang ada, (6) mengidentifikasi sudut pandang, dan (7) mengevaluasi bukti yang ditawarkan untuk mendukung pengakuan. Sedangkan Ennis (1996) memberikan sebuah definisi sebagai berikut, "Critical thinking is reasonable, reflective thinking that is fokused on deciding what to believe and do" yang artinya berpikir kritis adalah berpikir secara beralasan dan reflektif dengan menekankan pembuatan keputusan tentang apa yang harus dipercayai atau dilakukan.

\section{Kemampuan Awal}

Gange dalam Sudjana (1996) yang menyatakan bahwa " kemampuan awal lebih rendah dari kemampuan baru dalam pembelajaran, kemampuan awal merupakan prasyarat yang harus dimiliki peserta didik sebelum mengikuti materi pelajaran berikutnya yang lebih tinggi". Jadi peserta didik yang memiliki kemampuan awal yang baik akan lebih cepat memahami materi dibandingkan dengan peserta didik yang tidak memiliki kemampuan awal dalam proses pembelajaran.

Pengetahuan awal atau prior knowledge didefenisikan kemampuan awal sebagai 
keseluruhan pengetahuan aktual seseorang yaitu (1) telah ada sebelum pembelajaran, (2) terstrukturisasi dalam schemata, (3) sebagai pengetahuan deklaratif dan prosedural, (4) sebagai eksplisit, (5) mengandung pengetahuan isi dan pengetahuan metakognitif, (6) dinamis di alam dan tersimpan dalam basis pengetahuan awal (Dochy, 1996)

Pengetahuan awal seharusnya lebih rendah dari pengetahuan baru, sehingga dapat disimpulkan bahwa kemampuan awal adalah hasil belajar yang didapat sebelum mendapat kemampuan yang lebih tinggi, latar belakang pengetahuan atau kemampuan awal merupakan salah satu faktor yang menentukan. Walaupun belum tentu peserta didik yang mempunyai kemampuan awal tinggi daripada peserta didik lainnya. Kemampuan awal peserta didik merupakan prasyarat untuk mengikuti pembahasan materi berikutnya, sehingga memudahkan untuk dapat melaksanakan proses belajar dengan baik

Berdasarkan kajian teori, maka hipotesis penelitian inia adalah (i) ada perbedaan pemahaman konsep antara peserta didik yang dibelajarkan dengan model pembelajaran inkuiri terbimbing dengan peserta didik yang dibelajarkan model pembelajaran discovery learning; (ii) ada perbedaan kemampuan berpikir kritis antara peserta didik yang dibelajarkan dengan model pembelajaran inkuiri terbimbing dengan peserta didik yang dibelajarkan dengan model pembelajaran discovery learning; (iii) ada perbedaan pemahaman konsep antara peserta didik yang memiliki kemampuan awal rendah dan kemampuan awal; (iv) ada perbedaan kemampuan berpikir kritis antara peserta didik yang memiliki kemampuan awal rendah dan kemampuan awal tinggi; (v) tidak ada interaksi model pembelajaran dengan kemampuan awal peserta didik terhadap kemampuan berpikir kritis; (vi) tidak ada interaksi model pembelajaran dengan kemampuan awal peserta didik.

\section{METODOLOGI PENELITIAN}

Jenis penelitian ini adalah penelitian eksprimen semu ( quasi eksprimen) dengan memperhatikan variable kemampuan berpikir kritis, dan pemahaman konsep dalam proses pembelajaran dengan menggunakan pembelajaran model inkuiri terbimbing dan model pembelajaran discovery learning.
Populasi pada penelitian adalah seluruh peserta didik kelas X IPA Sma Negeri 22 Makassar semester genap tahun pelajaran 2014/2015 yang terbagi dalam empat kelas. Teknik pengambilan sampel dilakukan secara acak (simple random sampling) dengan asumsi bahwa populasi bersifat homogeny. Dari hasil penelitian sampel ditetapkan kelas X IPA 1 sebagai kelas eksprimen satu dibelajarkan dengan model pembelajaran discovery learning dengan jumlah peserta didik 35 orang dan kelas X IPA 2 sebagai kelas eksprimen dua yang dibelajarkan model pembelajaran inkuiri terbimbing dengan jumlah peserta didik 35 orang.

Variabel dalam penelitian ini adalah model pembelajaran, kemampuan berpikir kritis, pemahaman konsep, dan kemampuan awal. Defenisi operasional model Pembelajaran Inkuiri terbimbing adalah pembelajaran yang menekankan aktivitas peserta didik dalam mencari dan menemukan melalui penyelidikan untuk mengembangkan kemampuan berpikir kritis dan pemahaman konsep bagi peserta didik. Kemampuan berpikir kritis adalah kemampuan menganalisis, keterampilam mensintesis, kemampuana memecahkan masalah, kemampuan menyimpulkan, kemampuan mengevaluasi/ menilai. Pemahaman Konsep adalah kemampuan yang menunjukkan pemahaman konsep peserta didik terhadap materi larutan elektrolit dan nonelektrolit dalam menafsirkan, mengklasifikasikan, menyimpulkan, membandingkan, dan menjelaskan. Kemampuan awal adalah pengetahuan actual yang telah ada sebelumnya. Kemampuan awal dalam penelitian ini dibagi atas dua: kemampuan awal tinggi dan kemampuan awal rendah.

Instrumen dalam penelitian ini terdiri dari tes kemampuan berpikir kritis yang indikatornya berdasarkan Ennis, tes pemahaman konsep yang indikatornya berdasarkan Anderson, dan tes kemampuan awal yang meliputi materi ikatan kimia dan stokiometri, dengan kriteria penilaian yang diadaptasi dari penentuan nilai hasil belajar oleh Arikunto. Uji validitas instrumen menggunakan teknik validitas isi. Validitas isi dilakukan dengan meminta pertimbangan dua ahli mengenai kesesuaian indicator dan butir instrument yang di kembangka, kemuadian dilakukan teknik analisis deskriptif dan analisis inferensial. Uji normalitas dan uji homogenitas menggunakan bantuan SPSS versi 20. 


\section{HASIL DAN PEMBAHASAN \\ PENELITIAN}

\section{Hasil}

1. Kemampuan Berpikir Kritis Peserta Didik Berdasarakan Model Pembelajaran
Hasil analisis deskriptif mengenai pengaruh model pembelajaran inkuiri terbimbing dan discovery learning terhadap kemampuan berpikir kritis peserta didik pada materi pokok larutan elektrolit dan nonelektrolit disajikan pada Tabel 4.1

Tabel 4.1 Statistik Kemampuan Berpikir Kritis (KBK) Peserta Didik ditinjau dari Model Pembelajaran Inkuiri Terbimbing dan Discovery Learnig

\begin{tabular}{lcc}
\hline Statistik & $\begin{array}{c}\text { KBK Peserta Didik yang } \\
\text { Dibelajarakan Discovery } \\
\text { Learning }\end{array}$ & $\begin{array}{c}\text { KBK Peserta Dididk yang } \\
\text { Dibelajarakan Inkuiri } \\
\text { terbimbing }\end{array}$ \\
\hline N & 35 & 35 \\
Nilai maksimal & 100 & 100 \\
Mean & 72,3 & 78,4 \\
Median & 72 & 75,5 \\
Varians & 83,3 & 67,55 \\
Nilai terendah & 48,8 & 67 \\
Nilai tertinggi & 88,3 & 95 \\
Standar deviasi & 9,1 & 8,2 \\
Range & 39,5 & 28 \\
\hline
\end{tabular}

Deskripsi kemampuan berpikir kritis peserta didik yang dibelajarakan dengan model inkuiri terbimbing dan discovery learning dapat bentuk histogram disajikan pada gambar 4.1 dan 4.2 :

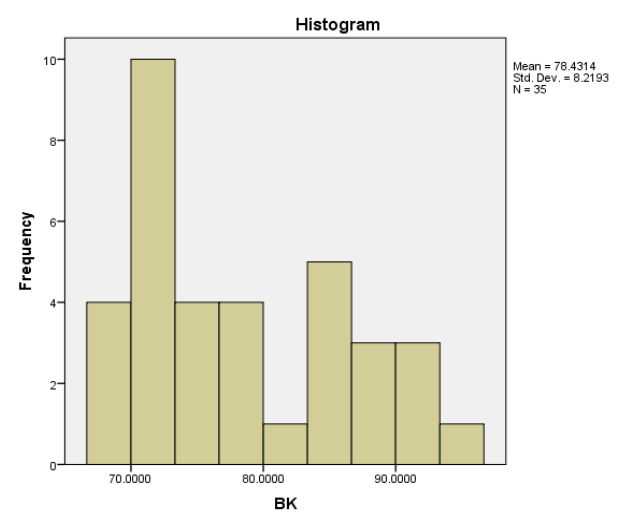

Gambar 4.1 Deskripsi hasil kemampuan berpikir kritis peserta didik yang dibelajarakan dengan model inkuiri terbimbing. 


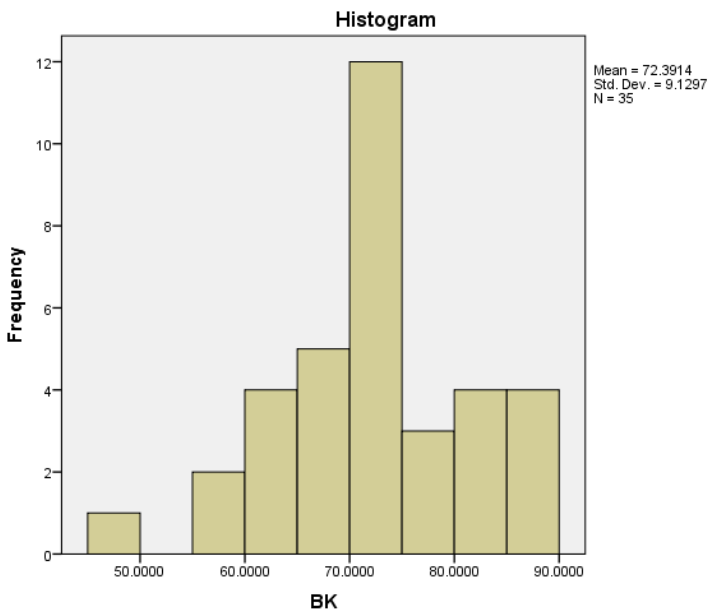

Gambar 4.2 Deskripsi hasil kemampuan berpikir kritis peserta didik yang dibelajarkan dengan model discovery learning

2. Pemahaman Konsep Peserta Didik Berdasarkan Model Pembelajaran.

Hasil analisis deskripstif pemahaman konsep peserta didik pada materi pokok larutan elektrolit dan nonelektrolit yang dibelajarkan dengan model pembelajaran discovery learning dan inkuiri terbimbing disajikan pada Tabel 4.2:

Tabel 4.2 Statistik Pemahaman Konsep (PK) Peserta Didik ditinjau dari Model Pembelajaran Inkuiri Terbimbing dan Discovery Learnig.

\begin{tabular}{lcc}
\hline Statistik & $\begin{array}{c}\text { PK Peserta didik yang } \\
\text { Dibelajarkan Discovery } \\
\text { Learning }\end{array}$ & $\begin{array}{c}\text { PK Peserta Didik yang } \\
\text { Dibelajarkan Inkuiri } \\
\text { Terbimbing }\end{array}$ \\
\hline $\mathrm{N}$ & 35 & 35 \\
Nilai maksimal & 100 & 100 \\
Mean & 75,07 & 74,77 \\
Median & 75 & 72 \\
Varians & 78,7 & 81 \\
Nilai terendah & 50 & 59 \\
Nilai tertinggi & 91,6 & 90 \\
Standar deviasi & 8,87 & 9,00 \\
Range & 41,6 & 31 \\
\hline
\end{tabular}

Deskripsi pemahaman konsep peserta didik yang dibelajarakan dengan model inkuiri terbimbing dan discovery learning dapat bentuk histogram disajikan pada gambar : 


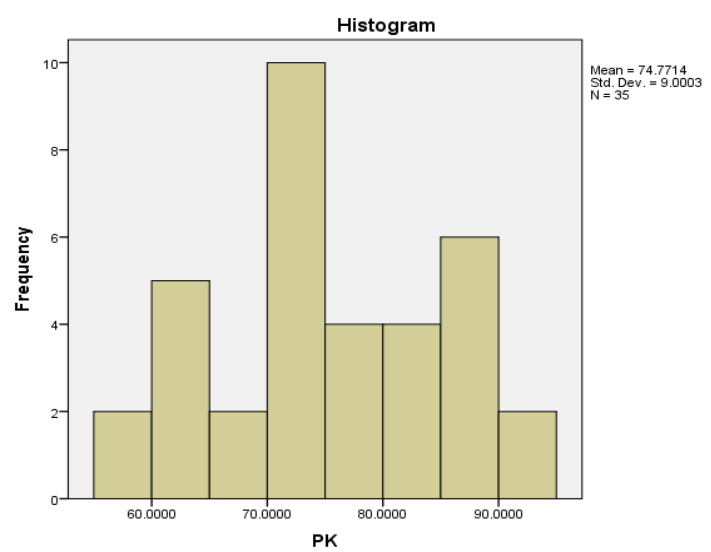

Gambar 4.3 Deskripsi hasil pemahaman konsep peserta didik yang dibelajarkan dengan model inkuiri terbimbing.

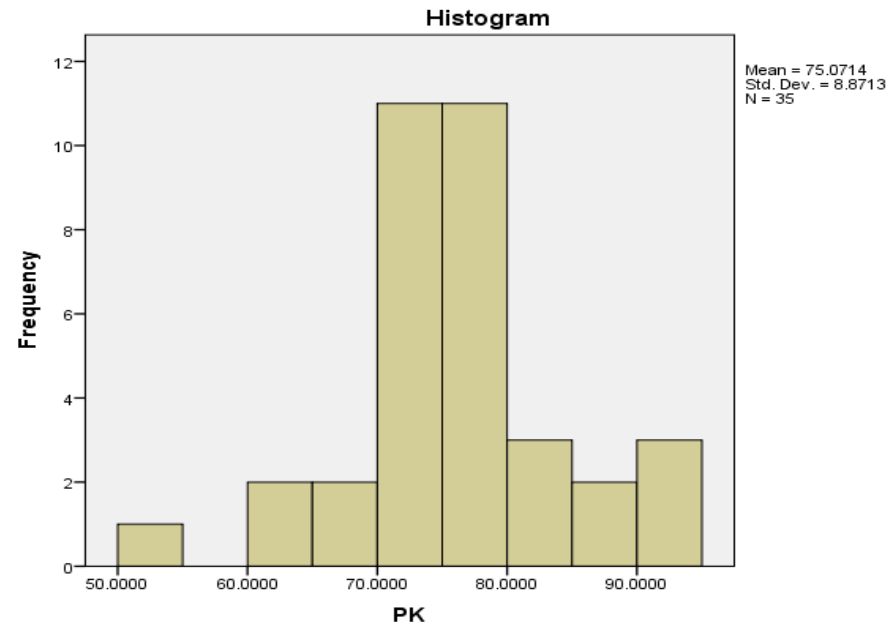

Gambar 4.4 Deskripsi hasil pemahaman konsep peserta didik yang dibelajarkan dengan model discovery learning

3. Kemampuan Berpikir Kritis Peserta Didik Berdasarkan Kemampuan Awal

Hasil analisis deskripstif kemampuan awal peserta didik pada materi pokok larutan elektrolit dan nonelektrolit terhadap kemampuan berpikir kritis disajikan pada Tabel 4.3:

Tabel 4.3 Statistik Deskriptif Kemampuan Awal Peserta Didik terhadap Kemampuan Berpikir Kritis

\begin{tabular}{ccc}
\hline Statistik & $\begin{array}{c}\text { KBK untuk Peserta Didik yang } \\
\text { Berkemampuan Awal Tinggi }\end{array}$ & $\begin{array}{c}\text { KBK Peserta Didik yang } \\
\text { Berkemampuan Awal } \\
\text { Rendah }\end{array}$ \\
\hline N & 37 & 33 \\
Nilai maksimal & 100 & 100 \\
Rata-rata & 78,23 & 72,24 \\
Median & 77,9 & 72,00 \\
Nilai tertinggi & 95,00 & 83,00 \\
Nilai terendah & 62,70 & 48,8 \\
Standar deviasi & 7,71 & 9,68 \\
\hline
\end{tabular}


Deskripsi kemampuan berpikir kritis peserta didik yang ditinjau dari kemampuan awal dapat bentuk histogram disajikan pada gambar :

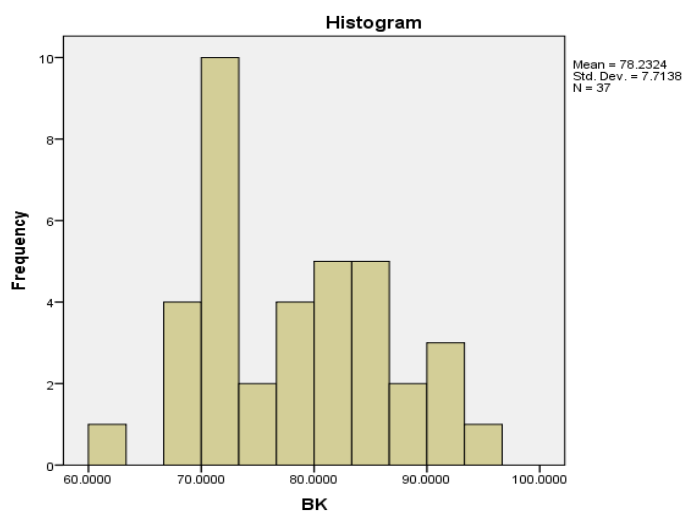

Gambar 4.5 Deskripsi kemampuan berpikir kritis peserta didik yang ditinjau dari kemampaun awal tinggi

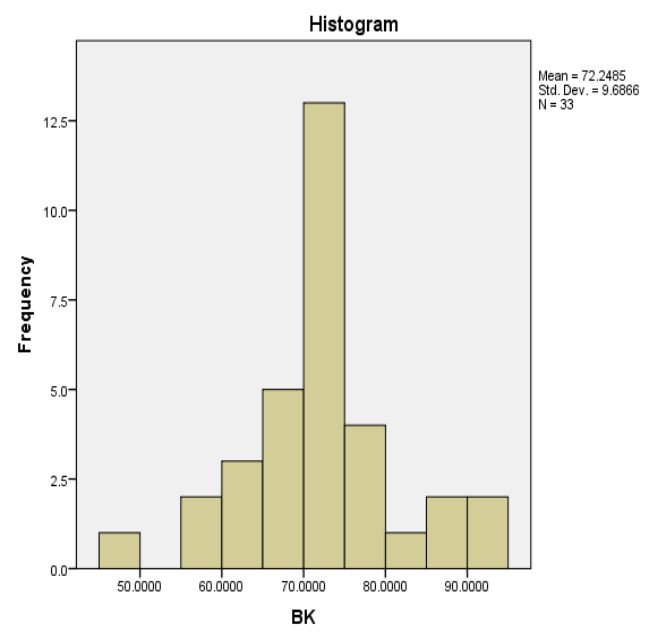

Gambar 4.6 Deskripsi kemampuan berpikir kritis peserta didik yang ditinjau dari kemampuan awal rendah

4. Kemampuan Awal terhadap Kemampuan Pemahaman Konsep Peserta Didik

Hasil analisis deskripstif kemampuan awal peserta didik pada materi pokok larutan elektrolit dan nonelektrolit terhadap kemampuan pemahaman konsep peserta didik disajikan pada Tabel 4.4:

Tabel 4.4 Statistik Deskriptif Kemampuan Awal Peserta Didik terhadap Pemahaman Konsep

\begin{tabular}{ccc}
\hline Statistik & $\begin{array}{c}\text { PK Peserta didik yang } \\
\text { Berkemampuan Awal Tinggi }\end{array}$ & $\begin{array}{c}\text { PK Peserta didik yang } \\
\text { Berkemampuan Awal } \\
\text { Rendah }\end{array}$ \\
\hline N & 37 & 33 \\
Nilai maksimal & 100 & 100 \\
Rata-rata & 79,23 & 70,08 \\
Median & 79,10 & 70,80 \\
Nilai tertinggi & 91,60 & 81,60 \\
Nilai terendah & 62,50 & 50,00 \\
Standar deviasi & 7,24 & 8,07 \\
\hline
\end{tabular}


Deskripsi pemahaman konsep peserta didik ditinjau dari kemampuan awal peserta didik dalam bentuk histogram disajikan pada gambar 4.7:

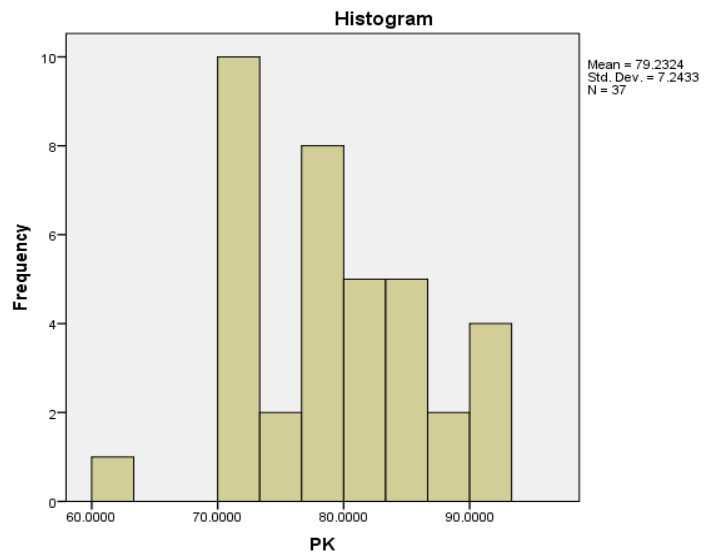

Gambar 4.7 Deskripsi pemahaman konsep peserta didik ditinjau dari kemampuan awal tinggi.

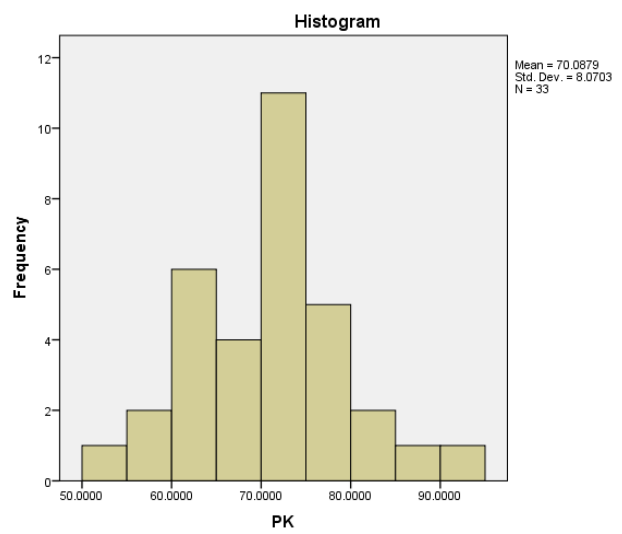

Gambar 4.8 Deskripsi pemahaman konsep peserta didik ditinjau dari kemampuan awal rendah.

5. Rata-rata simpangan baku dari jumlah anggota tiap kelompok ditinjau dari kemampuan berpikir kritis.

Tabel 4.5 Rata-rata simpangan baku dari jumlah anggota tiap kelompok ditinjau dari kemampuan berpikir kritis.

\begin{tabular}{llll}
\hline \multirow{2}{*}{ Kemampuan awal } & \multicolumn{2}{c}{ Kemampuan awal } & \multirow{2}{*}{ Jumlah } \\
\cline { 2 - 3 } Model pembelajaran & \multicolumn{1}{c}{ Tinggi } & \multicolumn{1}{c}{ Rendah } & \\
\hline \multirow{2}{*}{ Inkuiri terbimbing } & $\bar{x}=80,97$ & $\bar{x}=75,41$ & $\bar{x}=78,4$ \\
& $\mathrm{~s}=7,75$ & $\mathrm{~s}=7,9$ & $\mathrm{~s}=9,1$ \\
& $\mathrm{n}=19$ & $\mathrm{n}=16$ & $\mathrm{n}=35$ \\
\hline Discovery Learning & $\bar{x}=75,23$ & $\bar{x}=69,27$ & $\bar{x}=72,3$ \\
& $\mathrm{~s}=6,7$ & $\mathrm{~s}=10,43$ & $\mathrm{~s}=8,2$ \\
& $\mathrm{n}=18$ & $\mathrm{n}=17$ & $\mathrm{n}=35$ \\
\hline
\end{tabular}

6. Rata-rata simpangan baku dari jumlah anggota tiap kelompok ditinjau dari pemahaman konsep

Tabel 4.6 Rata-rata simpangan baku dari jumlah tiap anggota kelompok ditinjau dari pemahaman konsep.

\begin{tabular}{lll}
\hline Kemampuan awal & Kemampuan awal & Jumlah \\
\hline
\end{tabular}




\begin{tabular}{llll}
\hline Model pembelajaran & \multicolumn{1}{c}{ Tinggi } & \multicolumn{1}{c}{ Rendah } & \\
\cline { 1 - 3 } Inkuiri terbimbing & $\bar{x}=79,57$ & $\bar{x}=69,06$ & $\bar{x}=74,72$ \\
& $\mathrm{~s}=6,6$ & $\mathrm{~s}=8,1$ & $\mathrm{~s}=9,0$ \\
& $\mathrm{n}=19$ & $\mathrm{n}=16$ & $\mathrm{n}=35$ \\
\hline Discovery learning & $\bar{x}=78,86$ & $\bar{x}=71,05$ & $\bar{x}=75,07$ \\
& $\mathrm{~s}=7,9$ & $\mathrm{~s}=8,12$ & $\mathrm{~s}=8,87$ \\
& $\mathrm{n}=18$ & $\mathrm{n}=17$ & $\mathrm{n}=35$ \\
\hline
\end{tabular}

7. Perbedaan antara Selisih Model Pembelajaran dan Kemampuan Awal terhadap Kemampuan Berpikir Kritis Peserta Didik

Model pembelajaran dalam hal ini model pembelajaran inkuiri terbimbing dan model pembelajaran discovery learning tidak saling mempengaruhi kemampuan berpikir kritis peserta didik dalam proses pembelajaran . Hal ini dipertegas dengan grafik 4.9:

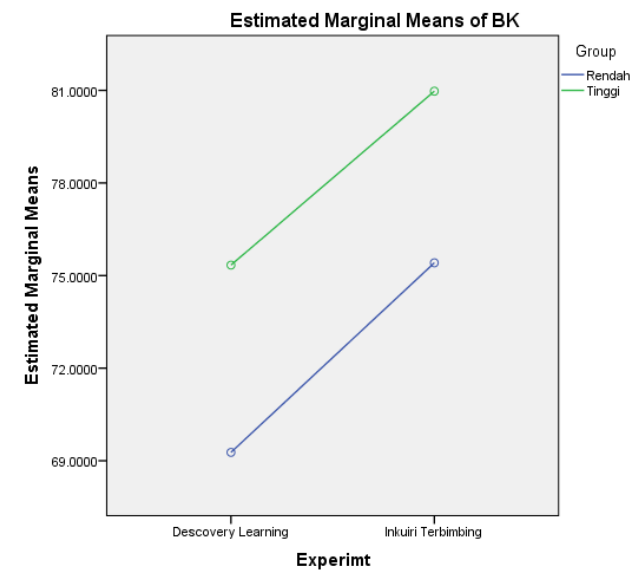

Gambar 4.1 Grafik Hubungan antara Model Pembelajaran dan Kemampuan Awal terhadap Kemampuan Berpikir Kritis Peserta Didik.

8. Perbedaan antara Selisih Model Pembelajaran dan Kemampuan Awal terhadap Pemahaman Konsep Peserta Didik.

tidak ada perbedaan antar selisih pemahaman konsep peserta didik yang berkemampuan awal tinggi dan kemampuan awal rendah yang dibelajarkan dengan model pembelajaran inkuiri terbimbing dan discovery learning. Hal ini dipertegas dengan grafik 4.10: 


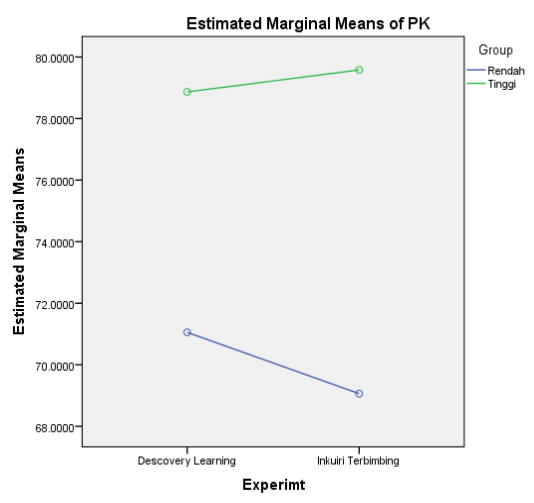

Gambar 4.2 Grafik Hubungan antara model pembelajaran dan kemampuan awal terhadap pemahaman konsep peserta didik

\section{Pembahasan}

1. Perbedaan kemampuan berpikir kritis peserta didik yang dibelajarkan dengan model pembelajaran inkuiri terbimbing dan model pembelajaran discovery learning.

Berdasarkan hasil penelitian diperoleh gambaran bahwa terdapat perbedaan kemampuan berpikir kritis peserta didik yang dibelajarkan dengan model pembelajaran discovery learning dan model pembelajaran inkuiri terbimbing. Model pemebelajaran discovery learning dan model pembelajaran inkuiri terbimbing memiliki kesamaan karasteristik. Keduanya merupakan model pembelajaran yang melibatkan peserta didik dalam proses pembelajaran. Meskipun banyak memiliki kesamaan tetapi model pembelajaran inkuiri terbimbing memiliki potensi yang amat besar dalam mengembangkan kemampuan berpikir kritis peserta didik

Perbedaan kemampuan berpikir kritis yang ditimbulkan kedua model ini yaitu pada model inkuiri terbimbing permasalahannya bukan hasil rekaya guru, sehingga peserta didik harus megerahkan seluruh kemampuan berpikir kritisnya untuk mendapatkan temuan-temuan di dalam masalah tersebut melalui proses penelitian, sedangkan model discovery learning permasalahan yang diperhadapkan kepada peserta didik semacam masalah yang direkayasa oleh guru. Perbedaan lainnya adalah dapat dilihat pada sintaks masing-masing model pembelajaran yang dihubungkan dengan kemampuan berpikir kritis, dimana pada model pembelajaran inkuiri terbimbing tahap orientasi masalah dan menemukan masalah yang diberikan merupakan persoalan yang harus dipecahkan, dimana persoalan tersebut disajikan dalam bentuk teka-teki untuk dicari penyelesaiannya melalui kegiatan menyelidiki. Sedangkan pada model discovery learning pada tahap stimulasi dan identifikasi masalah.

2. Perbedaan pemahaman konsep peserta didik yang dibelajarkan dengan model pembelajaran inkuiri terbimbing dan model pembelajaran discovery learning.

Berdasarkan hasil penelitian diperoleh gambaran bahwa tidak terdapat perbedaan pemahaman konsep peserta didik yang dibelajarkan dengan model pembelajaran discovery learning dan model pembelajaran inkuiri terbimbing. Model inkuiri terbimbing dan model discovery learning memiliki prinsip yang sama. Keduanya adalah model pembelajaran yang berbasis "penemuan", yang melibatkan peserta didik dalam mencari informasi dan menemukan solusi untuk menyelesaikan tugas-tugas pembelajaran. Meskipun banyak kemiripan, keunggulan model pembelajaran inkuiri terbimbing adalah membantu peserta didik memahami konsep, mendorong berpikir dan bekerja atas inisiatif sendiri serta merumuskan sendiri hipotesisnya. Sedangkan discovery learning memiliki potensi yang amat besar untuk membuat pengalaman belajar yang lebih menarik dan bermakna bagi peserta didik dalam penemuan konsep. Pada proses pembelajaran model discovery learning menekankan pembentukan kategori-kategori atau konsep-konsep yang dapat memungkinkan terjadi generalisasi (BPSDMPMP, 2014).

\section{Perbedaan kemampuan berpikir kritis peserta didik yang memiliki kemampuan awal tinggi dan kemampuan awal rendah.}


Berdasarkan hasil penelitian diperoleh gambaran bahwa ada perbedaan kemampuan berpikir kritis pada kemampuan awal peserta didik yang dibelajarkan dengan model pembelajaran inkuiri terbimbing dan discovery learning. Perbedaan kemampuan berpikir kritis ini terjadi karena setiap individu mempunyai karasteristik yang berbeda-beda dalam menerima dan merespon, mengolah informasi yang diberikan oleh guru sesuai dengan tingkat kemampuan awalnya. Dengan kemampuan awal yang tinggi memudahkan peserta didik terlibat secara aktif dalam proses pembelajaran melalui percobaan/eksprimen atau kajian literatur, sehingga melatih kemampuan berpikir kritisnya. Sardiman (2001) berpendapat bahwa peserta didik yang memiliki kemampuan awal yang tinggi memiliki motivasi yang besar dalam belajar dan cendrung aktif bertanya serta memiliki rasa ingin tahu yang lebih tinggi, sehingga lebih potensial berkembang kemampuan berpikir kritisnya. Sebaliknya peserta didik yang mempunyai kemampuan awal rendah cendrung memiliki motivasi tidak setinggi peserta didik yang berkemampuan awal tinggi.

4. Perbedaan pemahaman konsep peserta didik yang memiliki kemampuan awal tinggi dan kemampuan awal rendah.

Berdasarkan hasil penelitian diperoleh gambaran perbedaan pemahaman konsep peserta didik yang memiliki kemampuan awal tinggi dan kemampuan awal rendah. Pembelajaran dengan memperhatikan kemapuan awal akan memberikan dampak pemahaman konsep yang memadai (Ardhana, 2004). Dari sudut pandang konstruktivisme kemampuan awal merupakan spring board dan berfungsi sebagai entry level dalam perolehan belajar (Dochy, 1996). Peserta didik yang memiliki kemampuan awal yang tinggi akan memiliki motivasi positif dan tidak kesulitan dalam belajar. Hal ini sesuai dengan hasil penelitian Lazarowitz (2006) menyimpulkan bahwa pengetahuan awal dapat memandu siswa dalam proses pembelajaran dan mengkonstruksi pengetahuannya.

5. Perbedaan antar selisih kemampuan berpikir kritis peserta didik yang berkemampuan awal tinggi dan kemampuan awal rendah yang dibelajarkan melalui model pembelajaran inkuiri terbimbing dengan

\section{yang dibelajarakan model discovery learning}

Berdasarkan hasil penelitian diperoleh gambaran tidak ada perbedaan antar selisih model pembelajaran dengan kemampuan awal dalam mempengaruhi kemampuan berpikir kritis Model pembelajaran inkuiri terbimbing dan model pembelajaran discovery learning samasama menempatkan peserta didik sebagai subjek atau sebagai pusat pengajaran (student Centered) didalam kelas. Sehingga peserta didik yang berkemampuan awal tinggi yang cendrung unuk mandiri dalam pembelajaran unggul dalam kedua model pembelajaran ini dibandingkan peserta didik yang memiliki kemampuan awal rendah yang cendrung menerima struktur yang sudah ada dan sangat susah untuk terlibat aktif dalam proses pembelajaran kedua model ini. Peserta didik ini biasanya hanya menunggu teman yang lainnya menyelesaikannya. Hal ini disebabkan selain pengetahuan awal tentang materi yang dibelajarkankan minim, juga karena tidak terbiasa dengan model pembelajaran yang menuntut mereka bekerja keras untuk menemuka informasi terhadap materi baru, sehingga hasil penelitian ini menunjukkan tidak ada perbedaan antara selisih kemampuan berpikir kritis antara model pembelajaran dan kemampuan awal, maka tidak ada interaksi antara kemampuan awal dengan model pembelajaran dalam mempengaruhi kemampuan berpikir kritis peserta didik.

\section{Perbedaan antar selisih pemahaman konsep peserta didik yang berkemampuan awal tinggi dan kemampuan awal rendah yang dibelajarkan melalui model pembelajaran inkuiri terbimbing dengan model discovery learning.}

Berdasarkan hasil penelitian diperoleh gambaran tidak ada perbedaan antar selisih antara model pembelajaran dengan kemampuan awal dalam mempengaruhi pemahaman konsep. Model pembelajaran inkuiri terbimbing dan model pembelajaran discovery learning samasama menempatkan peserta didik sebagai subjek atau sebagai pusat pengajaran (student Centered) didalam kelas. Sehingga peserta didik yang berkemampuan awal tinggi yang cendrung unuk mandiri dalam pembelajaran unggul dalam kedua model pembelajaran ini dibandingkan peserta didik yang memiliki kemampuan awal rendah yang cendrung menerima struktur yang sudah ada dan sangat susah untuk terlibat aktif 
dalam proses pembelajaran untuk menemukan suatu konsep kedua model ini. Peserta didik ini biasanya hanya menunggu teman yang lainnya menyelesaikannya. Hal ini disebabkan selain pengetahuan awal tentang materi yang dibelajarkankan minim, juga karena tidak terbiasa dengan model pembelajaran yang menuntut mereka bekerja keras untuk menemuka informasi terhadap materi baru, sehingga hasil penelitian ini menunjukkan tidak ada perbedaan antara selisih pemahaman konsep antara model pembelajaran dan kemampuan awal, maka tidak ada interaksi antara kemampuan awal dengan model pembelajaran dalam mempengaruhi kemampuan berpikir kritis peserta didik.

\section{SIMPULAN DAN SARAN}

Berdasarkan hasil penelitian dan pembahasan yang dikaitkan dengan hipotesis dalam penelitian ini, maka dapat disimpulkan bahwa:

1. Ada pengaruh model pembelajaran terhadap kemampuan berpikir peserta didik, berdasarkan hasil analisis data model pembelajaran inuiri terbimbing memiliki nilai rata-rata yang lebih tinggi dibandingkan model pembelajaran discovery learning

2. Tidak ada pengaruh model pembelajaran terhadap pemahaman konsep peserta didik, berdasarkan hasil analisis data model pembelajaran inkuiri terbimbing dan model pembelajaran discovery learning memiliki rata-rata yang sama.

3. Ada pengaruh kemampuan awal terhadap kemampuan berpikir kritis peserta didik, peserta didik yang memiliki kemampuan awal yang tinggi memiliki kemampaun berpikir kritis yang baik.

4. Ada pengaruh kemampuan awal terhadap pemahaman konsep peserta didik, peserta didik yang memiliki kemampuan awal yang tinggi memiliki pemahaman konsep yang baik.

5. Tidak ada interaksi antara model pembelajaran dan kemampuan awal terhadap kemampuan berpikir kritis.

\section{SARAN}

Adapun saran yang diberikan dalam penelitian ini (i) Dalam mengajarkan larutan elektrolit dan nonelektrolit untuk melihat kemampuan berpikir kritis peserta didik disarankan menggunakan model pembelajaran inkuiri terbimbing; (ii) Dalam mengajarkan larutan elektrolit dan nonelektrolit untuk melihat pemahaman konsep peserta didik disarankan menggunakan model pembelajaran discovery learning; (iii) Bantuan guru masih tetap diharapkan dalam proses pembelajaran pada model pembelajaran discovery learning.

\section{DAFTAR RUJUKAN}

Arikunto, S. 2011. Dasar-dasar Evaluasi Pendidikan .Edisi revisi. Jakarta: Bumi Aksara.

AusuBel. 1963. The Psycology of Meaningful Verbal Learning . New York: Grune and Straton.

BPSDMPMP, 2014 . Materi Pelatihan Guru Implementasi Kurikulum 2013. Jakarta: Kementrian Pendidikan dan Kebudayaan.

Dahar, R.W. 2011. Teori-teori Belajar dan Pembelajaran. Jakarta: Erlangga.

Dick, Walter and Carey, L. 2001. The Sistematic Design of Instruction. Florida: Addinson-Wesley Educational Publishers Inc.

Dochy, F.J.R.C, 1996. Altematives in Assessment of Achievements, Leaming Processes and Prior Knowledge.. New York : Springer Science+Business Media.

Eggen, P., dan Kauchak, D. 2012. Strategi dan Model Pembelajaran. Jakarta: Indeks

Ennis, R. H. 1996. Critical Thinking. United States of Amerika: University of Illinois.

Gagne, R. 1985. The Cognitive Psychology of School Learning. Boston: Little Brown.

Gulo. 2002. Strategi Belajar Mengajar. Jakarta: Grasindo

Haury, D.L. 1993. Teaching Science through Inquiry, The US Departement of Education

Herron, J, dkk. 1977. Problem Associated With Concept Analysis. Journal of Science Education, 61 (2), 186-198.

Joyce \& Weil. 2002. Model of Teaching. Boston: Allyn and Bacon.

Lazarowitz, R., Lieb, C. 2006. Assessment Pretest to Identify College Student's Prior Knowledge, Concept, and Learning Difficulties in Biology. International Journal of Science and 
Mathematics Education. Vol4. Issue

4. Pp 741-762

Sanjaya, W. 2006. Strategi Pembelajaran Berorientasi Standar Proses Pendidikan. Jakarta: Kencana Prenadamedia Group.

Sardiman. 2001. Interaksi dan Motivasi Belajar Mengajar. Jakarta: Raja Grafindo Persada.

Slavin, E, R. 2009. Psikologi Pendidikan Teori dan Praktik. Jakarta: PT. Indeks.

Suyanti, R.D. 2010. Strategi Pembelajaran Kimia. Yogyakarta: Graha Ilmu

Syah, M. 2006. Psikologi Belajar. Jakarta : Raja Grafindo Persada

Trianto. 2007. Model-model Pembelajaran Inovatif Berorientasi Konstruktivistik. Jakarta: Prestasi Pustaka.

Trianto.2009. Mendesain Model Pembelajaran Inovatif-Progresif. Jakarta : Kencana Prenadamedia group. 